\title{
Experimental Investigation of Pipeline Corrosion in a Polluted Niger Delta River
}

\author{
Odutola Toyin Olabisi, Amobi Chukwuka \\ Department of Petroleum and Gas Engineering, University of Port Harcourt, Choba, Nigeria
}

\section{Email address:}

bissy.odutola@gmail.com (O. T. Olabisi)

\section{To cite this article:}

Odutola Toyin Olabisi, Amobi Chukwuka. Experimental Investigation of Pipeline Corrosion in a Polluted Niger Delta River. International Journal of Oil, Gas and Coal Engineering. Vol. 8, No. 1, 2020, pp. 17-21. doi: 10.11648/j.ogce.20200801.13

Received: December 16, 2019; Accepted: January 9, 2020; Published: January 21, 2020

\begin{abstract}
Several networks of pipelines in Nigeria oil and gas industry have failed catastrophically in the last two decades because most oil pipelines operate in a corrosive environment and transport corrosive fluids. This research experimentally investigates the corrosion of a carbon steel pipeline immersed in a typical Niger Delta Offshore Environment. The experiment was carried out using the gravimetric (weight loss) method. The carbon steel coupon was immersed in a sample of water collected from the Niger Delta sea and in seawater polluted by $0.5 \mathrm{~mol} / \mathrm{dm}^{3}, 1.0 \mathrm{~mol} / \mathrm{dm}^{3}, 1.5 \mathrm{~mol} / \mathrm{dm}^{3}$ and $2.0 \mathrm{~mol} / \mathrm{dm}^{3}$ tetraoxosulphate (VI) acid respectively. The coupons were retrieved and examined at 4-hour interval. It was discovered that in an unpolluted state, the seawater was not corrosive. However, when polluted by $0.5 \mathrm{~mol} / \mathrm{dm}^{3}, 1.0 \mathrm{~mol} / \mathrm{dm}^{3}, 1.5 \mathrm{~mol} / \mathrm{dm}^{3}$ and $2.0 \mathrm{~mol} / \mathrm{dm}^{3}$ tetraoxosulphate (VI) acid, corrosion occurred. The highest rate of corrosion was observed in the coupon dipped into the seawater sample polluted by $2.0 \mathrm{~mol} / \mathrm{dm}^{3}$ of tetraoxosulphate (vi) acid and the lowest corrosion rate observed in the least polluted seawater $0.5 \mathrm{~mol} / \mathrm{dm}^{3}$. Corrosion rate increased with increasing pollutants; therefore, it is imperative for oil operators to carefully dispose of their waste to prevent rapid corrosion of subsea pipelines and other offshore facilities.
\end{abstract}

Keywords: Corrosion, Niger Delta, Carbon Steel Pipes, Pollution

\section{Introduction}

Corrosion in pipelines is one of the significant challenges faced in the oil and gas industries all over the world. This has made corrosion control or management a major factor to consider before setting up any industry that will transport products via pipeline. Corrosion is a natural process, which converts a refined metal to a more chemically stable form, such as its oxide, hydroxide or sulfide. It is the gradual destruction of materials (usually metals) by chemical and/or electrochemical reaction with their environment. It occurs as a result of some external and internal factors such as the composition of the fluid flowing through the pipeline, the pipeline material, presence of oxygen, salt and other dissolved chemicals in the environment [1].

As oil transportation facilities such as pipelines, flowline and storage tanks (vessels) age, they would start to corrode either as a result of oxidation or the presence of corrosive gases such as $\mathrm{CO}_{2}$ and $\mathrm{H}_{2} \mathrm{~S}$ [2]. This will continue to aggravate, especially if adequate protective measures are not taken, thereby causing the facilities to lose their thickness to corrosion. Consequences of corrosion are often more serious than the simple loss of a mass of metal. Corrosion may result in the reduction of metal thickness leading to loss of mechanical strength and structural failure or breakdown [3]. It can also cause perforation of vessels and pipes, allowing the escape of their contents and possible harm to the surroundings. Corrosion causes mechanical damage to valves, pumps, etc., and loss of mechanical strength and surface properties of a metallic component. Corrosion products can contaminate the fluids in vessels and pipes and may even block the pipes [4]. All these have a huge impact on the economy, environment and safety.

Pipelines are the major medium of crude oil and gas transportation. Pipeline corrosion can result in rupturing or leaking of production infrastructure. This occurs in production facilities that are very old and lack regular inspection and maintenance [5]. It is imperative to understand the rate of corrosion in pipelines and the factors that can cause or increase the rate of corrosion in a pipe. Most petroleum pipelines are made of carbon steel. This paper experimentally investigates the rate of corrosion of 
carbon steel pipelines in a typical Niger Delta offshore environment. The Niger Delta is the delta of the Niger directly sitting on the Gulf of Guinea on the Atlantic Ocean in Nigeria. Crude oil has been produced from the oil-rich Niger Delta for over 50 years in onshore fields and more recently in offshore regions.

\subsection{Corrosion}

Pipelines basically corrode externally and internally. Internal corrosion may be due to chemical reactions on the internal surfaces of the pipelines or equipment or material loss due to microbiological reactions, which are also electrochemical. Corrosion on the internal wall of a gas pipeline can occur when the pipe wall is exposed to water and contaminant in gas such as $\mathrm{O}_{2}, \mathrm{H}_{2} \mathrm{~S}, \mathrm{CO}_{2}$ or chlorides. The nature and extent of the corrosion damage that may occur are functions of the concentration and particular combinations of the various corrosive constituents within the pipe, as well as the operating conditions of the pipeline. The internal corrosion of risers or pipelines is affected by the pressure and velocities of the gas and liquids, among other factors.

External corrosion involves the corrosion of the external wall of the pipe. For buried pipes, the corrosivity of the soil can be determined from the soil electrical resistivity. This is because conductivity in soils is governed by the conductivity of pore fluids and tortuosity. The higher the tortuosity, the lower the electrical conduction. The electrical resistivity of the soil is a parameter that depends mainly on the salt concentration in the pore fluid, particle size, and the tortuosity of the conduction path, the latter being related to the porosity and structure [6]. Other factors to investigate before burying a pipe include soil $\mathrm{pH}$, and the presence of chlorides and sulfides.

In the offshore environment, there are three distinct areas or zones of corrosion on an offshore platform: the atmospheric zone, splash zone, and the zone of continuous immersion [7]. Subsea pipelines are in the zone of continuous immersion and will require a lot of protection from the corrosion. This is because the offshore environment is highly corrosive due to special stresses in the offshore environment [8] and the presence of dissolved salt, other chemical pollutants in the subsea environment. Several protective measures have been used in preventing subsea pipeline corrosion such as coating with bitumen and epoxy powder coating or the use of aluminium alloys. Subsea pipelines immersed in seawater with a neutral or slightly basic $\mathrm{pH}$ may corrode at a very low rate of about 1 mpy or less [9].

\subsection{Corrosion Chemistry}

Metals are obtained from their ores or naturally-occurring compounds by the expenditure of large amounts of energy (Figure 1). They are therefore in a metastable state and will tend to lose their energy by reverting to compounds more or less similar to their original states. Metallic pipelines get corroded as a result of age, the corrosive nature of the contacting soil, nature of the fluid being transported, and other environmental factors. Once corrosion commences from a point on a pipeline an anodic-cathodic condition is created; part of the pipeline become anodic, while the other part which is not badly damaged by corrosion is the cathodic, hence fast transfer of electrons takes place between cathode and anode. If this is not nipped on time, the fluid in the pipe starts sipping through the first layer lithology [11].

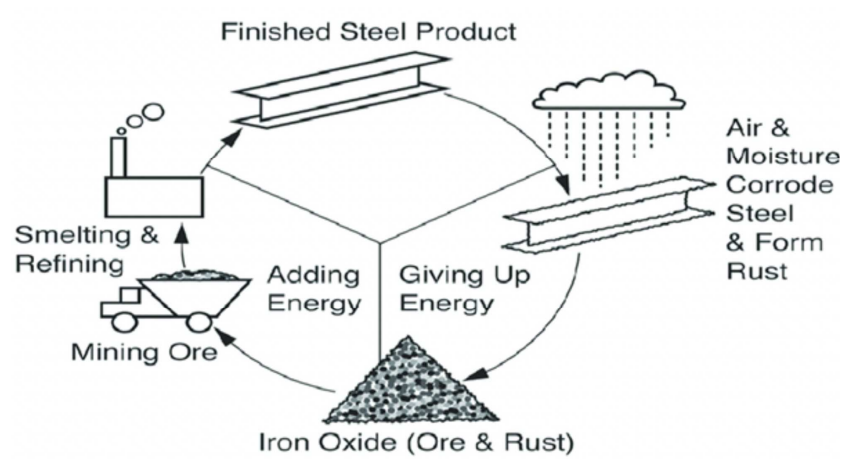

Figure 1. Corrosion cycle of metals [10].

The aqueous environment is the electrolyte in the corrosion process, through which the electron travels from anode to cathode (i.e., high-potential to low-potential metal). The corrosion process involves the removal of electrons (oxidation) of metal and the consumption of those electrons is termed reduction reactions, often indicated by the presence of oxygen or reduction of water from the aqueous environment, electrolyte, etc. The oxidation reaction is an anodic reaction in which the metal loss occurs, while the reduction reaction is a cathodic reaction.

The oxidation loss at the anode must be balanced with consumption of emitted electrons at the cathodic end. This charge neutrality is essential for the corrosion process to occur and continue. If, however, this is not maintained and the accumulation of large negative charges between the metal and electrolyte occurs, then gradually the reaction reduces and eventually stops the corrosion process. These reactions can occur within the metal itself (Half-Cell) even though they are not physically separated; when they are physically separated, the reaction is referred to as a corrosion cell.

A corrosion cell must have the following four components to be active: an anode (where electrons are emitted), a cathode (where electrons collect), a metallic path (the structure itself), and an electrolyte (conducting fluid, water, or soil) in which the anode and cathode are immersed. In controlling corrosion, it is desired that any one of these four essential elements should be removed from the corrosion cell to stop the corrosion process. The role of corrosion monitoring is: to determine conditions, extent and rate of corrosion. Corrosion monitoring practical field techniques include potential survey, corrosion coupons, bacteria count and intelligent pigging [12].

A corrosion coupon is a sacrificial element that is inserted into the pipe flow stream to measure the corrosive effect of the stream on the material of which the coupon is composed. It is 
an inexpensive method for monitoring the corrosion rate in different systems [13]. It is inserted for a sufficient for a length of time to get a measurable loss of coupon material from which the characteristics corrosion rate (grams/unit time) is deduced for the particular stream. Coupons are usually strips, rods or discs in form and are made of carbon steel but can be made with other available alloys. Weight loss coupons remain the standard technique for corrosion monitoring. They are used to predict a pipe's lifetime or design a corrosion inhibition treatment program for the piping system.

\subsection{Pipeline Corrosion in the Niger Delta}

Several researchers have worked on pipeline corrosion in the Niger Delta. However, their focus has been on buried pipelines. Okiongbu [6], worked on the corrosivity of the top three meters of the soil along a pipeline route using soil electrical resistivity for the emplacement of a conduit intended to serve as a gas pipeline in a Niger-Delta basin. It was established that Vertical Electrical Sounding (VES) is useful for predicting the degree of corrosiveness or aggressiveness of subsoil. The low resistivity values along the pipelines are the area of significant corrosion cells. Anyanwu et al. [14] worked on the experimental correlation between soil properties and external corrosion growth of carbon steel. In their work, they placed four pieces of X42 coupons in four different soil samples gotten from four different states in Niger Delta region for 2352 hours, to study the influence of soil properties towards metal via the weightloss method. It was observed that the resistivities of most samples increased with time, leading to an increase in the corrosion rate. Uko et al., [11] worked on the characteristics of soils for underground pipeline laying in the southwest Niger Delta, using thirty vertical sounding resistivities at specified locations. Results indicated that low resistivity values were observed in the upper three, four layers from the surface $0 \mathrm{~m}$ to a depth of about $15 \mathrm{~m}$, which is within the region of the proposed burial depth of the pipeline. In contrast, the fifth to the seventh layers have higher resistivity values indicative of less conductive regions. Chinwko et al. [15] experimentally investigated the effect of corrosion on mild steel in five different environments, namely; $0.1 \mathrm{~mol}$ of hydrochloric acid, underground soil, atmosphere, saltwater, freshwater using mild steel coupon for a period of five weeks weighing and re-immersing at intervals. It was observed that the rate of mild steel corrosion in the various media decreases in the following manner: $0.1 \mathrm{~mol}$ hydrochloric acid, underground (soil), saltwater, freshwater and the atmosphere. This implies that corrosion proceeded at a faster rate in the presence of ions, pollutants and acidic medium.

Due to limited published research on corrosion of Niger Delta subsea pipelines, this study investigates the effect of Niger Delta water on subsea pipelines. A carbon steel coupon was used to determine the extent at which carbon steel pipelines will corrode in a typical Niger delta offshore environment with varying concentration of tetraoxosulphate (VI) acid pollutant

\section{Methodology}

The materials/reagents used in this research are water sample from a particular Niger Delta River, Concentrated Tetra oxo sulphate (vi) acid (98\% pure), Acetone, Ethanol, Distilled water, carbon steel Coupon and thread. The equipment used in the course of this experiment are three conical flasks with corks, Two beakers, Mettle AE 160 weighing balance and Desiccators.

\subsection{Procedure}

The pipeline steel material was obtained and cut into a dimension of $3 \mathrm{~cm}$ by $2 \mathrm{~cm}$ coupon. A hole was drilled at the upper centre of the metals to allow the passage of thread for suspension of the coupon into the test solution. The coupons were polished with sandpaper to remove the protective films and impurities, and they were immersed in ethanol for five minutes, rinsed with distilled water afterwards and then dipped in acetone before they were weighed with the mettle AE 160 weight balance and allow to dry in the air. When dry, the coupons were preserved in a desiccator to avoid contamination before use in the experiment.

The seawater sample was contaminated with the varying volume of Tetraoxosulphate (vi) acid: $0.5 \mathrm{~mol} / \mathrm{dm}^{3}, 1.0$ $\mathrm{mol} / \mathrm{dm}^{3}, 1.5 \mathrm{~mol} / \mathrm{dm}^{3}$, and $2.0 \mathrm{~mol} / \mathrm{dm}^{3}$ of Tetraoxosulphate (vi) acid was added to the $200 \mathrm{ml}$ respectively to simulate different offshore conditions with varying acidity.

\subsection{Gravimetric Method}

The pre-cleaned metal coupons were weighed prior to commencement of the weight loss experiment. Each metal coupon was labelled with a rubber thread and a masking tape and dipped in one of the four different contaminated seawater solutions. At an interval of four hours, the coupon was brought out from the polluted seawater solution and immersed in distilled water to stop the reaction. The coupon was then degreased by immersing in ethanol and acetone for five minutes. Next, the coupons are brought out to dry and are weighed. The equivalent loss is calculated using:

$$
\Delta W=W_{i}-W_{f}
$$

Where,

$\mathrm{w}_{\mathrm{i}}=$ initial weight of coupon.

$\mathrm{w}_{\mathrm{f}}=$ final weight of coupon after corroding.

The corrosion rate is estimated using equation 3 .

$$
\text { Corrosion Rate }=\frac{\text { Weight loss } * k}{\text { density } * \text { area } * \text { time }}
$$

$\mathrm{K}=$ constant, which can be varied in other to calculate the corrosion rate in various units (table 1)

Table 1. Different K-factor values for calculating corrosion rate (Metal Sample company).

\begin{tabular}{lll}
\hline Desired corrosion rate unit & Area unit & k-factor \\
\hline Mils/year (mpy) & $\mathrm{In}^{2}$ & $5.34 \times 10^{5}$ \\
Mils/year (mpy) & $\mathrm{Cm}^{2}$ & $3.45 \times 10^{5}$ \\
Millimeter/year (mm/y) & $\mathrm{Cm}^{2}$ & $8.75 \times 10^{4}$ \\
\hline
\end{tabular}




\section{Results and Discussions}

A coupon was immersed in the seawater sample for 24 hours, and there was no significant change in the weight of the metal and no noticeable changes in the appearance of the metal. This implies that the coupon immersed in sample seawater for 24 hours did not corrode. Therefore, the seawater sample under study is not very corrosive in the time under study. Four coupons were immersed in the different seawater samples polluted by $0.5 \mathrm{~mol} / \mathrm{dm}^{3}, 1.0 \mathrm{~mol} / \mathrm{dm}^{3}, 1.5$ $\mathrm{mol} / \mathrm{dm}^{3}$, and $2.0 \mathrm{~mol} / \mathrm{dm}^{3}$ of Tetraoxosulphate (vi) acid.

A thin black film was observed around all coupons immersed in $0.5 \mathrm{~mol} / \mathrm{dm}^{3}, 1.0 \mathrm{~mol} / \mathrm{dm}^{3}, 1.5 \mathrm{~mol} / \mathrm{dm}^{3}$, and 2.0 $\mathrm{mol} / \mathrm{dm}^{3}$ of Tetraoxosulphate (vi) acid polluted seawater after 4 hours. It was also observed that the coupon corroded rapidly in the first 4 hours of the experiment (Figure 2). With increasing time, the rate of corrosion reduced.

After the $16^{\text {th }}$ hour towards $20^{\text {th }}$ hour, there was an increase in weight; this was as a result of the coupon forming a protective film around it, hence protecting it from the host environment. Corrosion still continued due to continued exposure to the polluted seawater but at a slower rate (Figure 2).

The first 16 hours of the experiment had increased corrosion rate prior to the formation of the protective film, which eventually slows down the rate of corrosion from the $16^{\text {th }}-28^{\text {th }}$ hour. The coupons corroded in a similar trend when immersed in 0.5 $\mathrm{mol} / \mathrm{dm}^{3}, 1.0 \mathrm{~mol} / \mathrm{dm}^{3}, 1.5 \mathrm{~mol} / \mathrm{dm}^{3}$, and $2.0 \mathrm{~mol} / \mathrm{dm}^{3}$ of Tetraoxosulphate (vi) acid polluted seawater. This implies that it is imperative to protect the pipe against corrosion. Once corrosion commences, rapidly depletes the metal until a protective film is formed that slows down the rate of the corroding pipe.

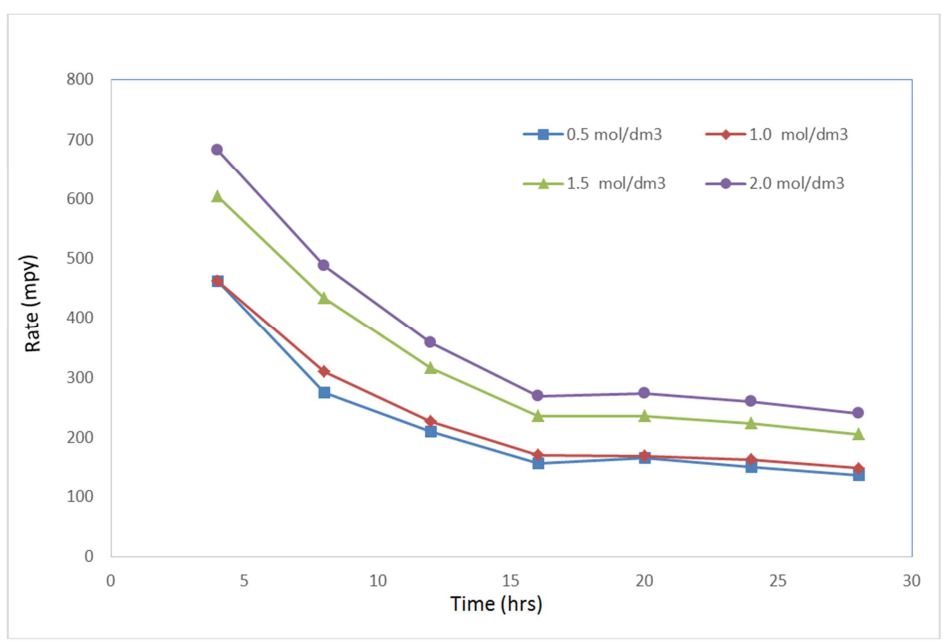

Figure 2. Corrosion rate versus Time in $0.5 \mathrm{~mol} / \mathrm{dm}^{3}, 1.0 \mathrm{~mol} / \mathrm{dm}^{3}, 1.5 \mathrm{~mol} / \mathrm{dm}^{3}$ and $2.0 \mathrm{~mol} / \mathrm{dm}^{3}$ Tetraoxosulphate (IV) acid polluted seawater

Also notice that the rate of corrosion in the coupon immersed in $0.2 \mathrm{~mol} / \mathrm{dm}^{3}$ was higher than the corrosion rate of coupon immersed in $0.5 \mathrm{~mol} / \mathrm{dm}^{3}, 1.0 \mathrm{~mol} / \mathrm{dm}^{3}, 1.5 \mathrm{~mol} / \mathrm{dm}^{3}$ tetraoxosulphate (IV) polluted seawater. This implies that an increase in the pollutant can rapidly increase the corrosion rate (Figure 2). In the plot of cumulative corrosion rate against time (Figure 3), it can be deduced that the lower the concentration of the pollutant (tetraoxosulphate (VI) acid), the lower the cumulative rate of corrosion. Notice that at 28hours, the
$2.0 \mathrm{~mol} / \mathrm{dm} 3$ polluted seawater had the highest cumulative corrosion rate of about $2572 \mathrm{mpy}$ while the $1.5 \mathrm{~mol} / \mathrm{dm} 3$ polluted seawater had a cumulative corrosion rate of $2253 \mathrm{mpy}$. The cumulative corrosion rate for $1.0 \mathrm{~mol} / \mathrm{dm} 3$ polluted seawater was $1652 \mathrm{mpy}$ while that of $0.5 \mathrm{~mol} / \mathrm{dm} 3$ polluted seawater was $1560 \mathrm{mpy}$. Oil producers need to keep the seawater free from pollutants when discharging wastes to the sea as this can have a bad effect on subsea pipelines and increase the rate of corrosion of these pipes.

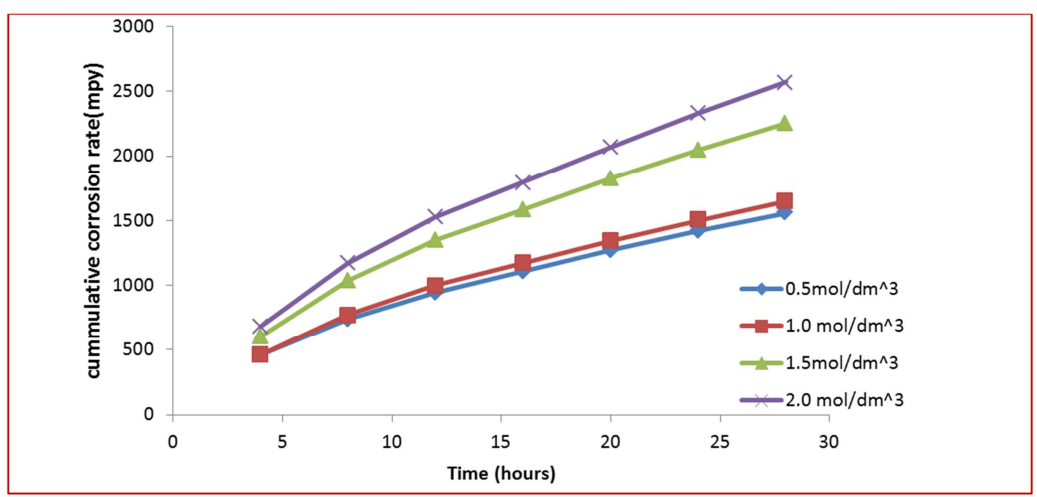

Figure 3. A graph of cumulative. Corrosion rate vs time in varying concentrations of polluted seawater. 


\section{Conclusion}

Carbon steel coupon was used in representing oil pipelines in this study as pipelines are made of carbon steel. The coupon did not corrode when immersed in the sample of seawater for 24 hours. Corrosion was noticed when the coupon was immersed in seawater samples polluted with varying concentrations of tetraoxosulphate (V1) acid. An increase in the concentration of the pollutant showed an increase in the corrosion rate and the cumulative corrosion rate. The highest rate of corrosion was noticed in the coupon immersed in seawater polluted by tetraoxosulphate (V1) acid. It is imperative to keep the seawater clean as pollution does not only harm aquatic life but can cause rapid corrosion of subsea facilities.

\section{References}

[1] Ozumba, U. I., (1997)," Sabotage and corrosion spills in SPDC-W, 1987-1996", Vol 13 no 1: 3-49.

[2] Umezurike, C (1999), Combating Oil Spillage with Chemical Dispersants. NICA. Proc. of 2nd Int'l Corr. Conf. Abuja, Nigeria

[3] Eker B. and Yuksel E. (2005): Solutions to Corrosion Caused by Agricultural Chemicals, Trakia Journal of Sciences, Vol. 3, No. 7, pp 1-6.

[4] Umoren S. A. (2009): Polymers as Corrosion Inhibitors for Metals in Different Media - A Review, The Open Corrosion Journal, 2009, 2, 175-188, pp 175-188

[5] Nwilo, P. C and Badejo, O. T., (2001),"'Impact of oil spills along the Nigeria coast" (International Journal of Environmental Health). Vol 04.

[6] Okiongbo, K. (2013). Predicting Soil Corrosivity along a Pipeline Route in the Niger Delta Basin Using Geoelectrical
Method: Implications for Corrosion Control. Engineering. 05. 237-244. 10.4236/eng.2013.53034.

[7] Hedborg C. E. (1974): "Corrosion in the Offshore Environment" paper OTC-1958-MS presented at sixth Annual Offshore Technology Conference held in Houston, Texas, May 6-8, 1974.

[8] Speight J. G.(2011): Chapter 8- Corrosion in Subsea and Deepwater Oil and Gas Technology, pages 213-256, Gulf Professional Publishing

[9] George V. C., Ryan M., and Ghazi D. A., in The Fundamentals of Corrosion and Scaling for Petroleum \& Environmental Engineers, 2009, Gulf Publishing Company

[10] Richard W. Drisko and James F. Jenkins (2005) "Good Painting Practice: SSPC Painting Manual" Volume 1, Fourth Edition, SSPC: The Society for Protective Coatings, Pp: 29-39

[11] Uko, E. D., Benjamin F. S. and Tamunobereton-ari, I. "Characteristics Of Soil For Underground Pipeline Laying In The Southwest Niger Delta”, vol 04, page 5, 2014.

[12] Kjellerup, B. V.; G. Gudmonsson, K. Sowers and P. H. Nielsen., (2006). Evaluation of Analytical Method for Determining the Distribution of Biofilm and Active Bacteria in a Commercial Heating System, Journal of Biofouling, vol 22: 133-139.

[13] Devesh P. K., Akshay P. S. and Himanshukumar R. P. (2018): IOSR Journal of Electrical and Electronics Engineering (IOSR-JEEE), Volume 13, Issue 2 Ver. I (Mar. - Apr. 2018), PP 85-93.

[14] Anyanwu, S. I., Nwosu, H. U., Reginald, A. E., Eseonu, O., (2014)."Correlation between soil properties and external corrosion growth rate of carbon steel (international Journal of Engineering and science), vol, page no 38-47.

[15] Chinwko, E. C., Odio, B. O., Chukwuneke, J. L., Sinebe, J. E., (2014), "Investigation of the effect of corrosion on mild steel in five different environments", international journal scientific and technology research, vol 3, issue 7, July 2014. 